\title{
Implementasi Forward Chaining dan Certainty Factor pada Aplikasi Konsultasi Kecantikan
}

\author{
Bunga Ratna Sari, Sabar Rudiarto \\ Fakultas Ilmu Komputer, Universitas Mercu Buana, Jakarta
}

\section{ARTICLE INFORMATION}

Received: January $15^{\text {th }}, 2021$

Revised: February $27^{\text {th }}, 2021$

Available online: March 31 ${ }^{\text {st }}, 2021$

\section{KEYWORDS}

Forward Chaining, Certainty Factor, Beauty

Clinic, Consultation, Expert System

\section{CORRESPONDENCE}

E-mail:

41516120068@student.mercubuana.ac.id

Sabar.rudiarto@mercubuana.ac.id

\section{A B S T $\mathbf{T}$ A C $\mathbf{C}$}

\section{PENDAHULUAN}

Bagi sebagian wanita di Indonesia khususnya, perawatan wajah menjadi hal yang sangat penting. Selain untuk mempercantik diri, perawatan juga memiliki banyak manfaat bagi kulit. Sama seperti bagian tubuh lain, kulit wajah juga memerlukan nutrisi agar tetap sehat dan terhindar dari berbagai macam masalah. Untuk hasil terbaik, perawatan wajah harus dilakukan sesuai dengan jenis dan kondisi kulit masing-masing, serta tidak boleh dilakukan secara sembarangan. Perawatan wajah umumnya dapat dilakukan di klinik kecantikan yang berada dibawah naungan dokter spesialis atau ahli kecantikan untuk menghindari kesalahan prosedur [1]. Namun saat ini, marak beroperasi salon kecantikan yang tidak berada dibawah tanggung jawab seorang dokter spesialis, dan juga produk-produk yang mengandung bahan berbahaya yang memberi klaim dapat mengatasi masalah dengan cepat membuat sebagian wanita merasa tergiur. Hal ini dikarenakan harga yang tergolong sangat murah dan juga tidak perlu mengeluarkan biaya tambahan untuk konsultasi dengan dokter. Padahal perawatan yang tidak sesuai dengan prosedur dan produk yang mengandung bahan berbahaya justru akan memberikan dampak negatif dan masalah yang jauh lebih kompleks dari kondisi awal jika tidak sesuai dengan kebutuhan dasar kulit yang sesungguhnya.
Kasus tersebut biasa ditemukan pada penggunaan kosmetik ilegal yang mengandung bahan berbahaya seperti merkuri. Seperti dilansir dalam siaran pers BPOM dengan judul artikel "Lindungi Masyarakat dari Obat Tradisional, Suplemen Kesehatan, dan Kosmetik yang Berisiko terhadap Kesehatan, Badan POM Kembali Terbitkan Public Warning" yang dipublikasikan dalam pada tanggal 2 Juli 2020, bahwa bahan tersebut secara umum dapat menyebabkan kanker(karsinogenik), kelainan pada janin (teratogenik) dan iritasi kulit. Oleh karena itu, melakukan konsultasi dengan dokter spesialis menjadi hal yang sangat diperlukan sebelum memutuskan untuk melakukan perawatan dan penggunaan suatu produk untuk menghindari dampak negatif dari kesalahan tersebut.

Ari Puspita, Ade Fitria Lestari dan Hilda Amalia telah melakukan sebuah penlitian dan membuat jurnal dengan judul "Sistem Pakar Pendeteksian Dini Jenis dan Perawatan Kulit Wajah dengan Menggunakan Metode Forward Chaining” [2] pada tahun 2017. Hasil dari penelitian ini menyimpulkan bahwa pendeteksian menggunakan metode forward chaining sangat cocok diterapkan untuk studi kasus tersebut, karena metode forward chaining menelusuri suatu masalah berdasarkan fakta yang ada sebelum memberikan simpulan sebagai hasil akhirnya. Kemudian pada tahun 2019, Indyah Hartami Santi dan Bina Andari melakukan penelitian dengan judul "Sistem Pakar Untuk Mengidentifikasi 
Jenis Kulit Wajah dengan Metode Certainty Factor" [3] . Metode ini digunakan untuk mengukur tingkat keyakinan atas sebuah hasil berdasarkan bobot yang diberikan oleh 2 pihak yaitu user dan pakar ke dalam sistem. Hasil akhir dari penelitian berdasarkan studi kasus menunjukkan bahwa penggunaan metode certainty memberikan derjat keyakian tertinggi sebesar 95,3344\% untuk kulit sensitif.

Penelitian ini bertujuan untuk membuat sistem pakar yang dapat mengidentifikasi masalah kulit wajah seseorang berdasarkan gejala yang ada. Sehingga masyarakat bisa lebih memahami masalah kulitnya dan mencari pengobatan yang diperlukan tanpa harus membayar biaya konsultasi. Metode forward chaining dan faktor kepastian dipilih dalam penelitian ini karena memiliki kelebihan dalam pengambilan kesimpulan berdasarkan data dan fakta yang dimiliki oleh para ahli. Metode Forward Chaining digunakan untuk menarik kesimpulan berdasarkan fakta-fakta yang dimasukkan. Sedangkan faktor kepastian digunakan untuk menghitung nilai kepercayaan dari kesimpulan. Dengan penggabungan kedua algoritma tersebut dalam penelitian ini diharapkan dapat meningkatkan akurasi dalam melakukan diagnosa terhadap masalah kulit seseorang.

Dalam penulisan penelitian ini terdapat 5 bagian utama yang disajikan, bagian I Pendahuluan yang menjelaskan mengenai latar belakang, kemudian bagian II Metode yang menjelaskan mengenai jenis penelitian dan tahapannya. Bagian III Hasil dan Pembahasan menjelaskan mengenai hasil dari penelitian yang dilakukan, kemudian bagian IV Kesimpulan berisi mengenai hasil dari penelitian yang merupakan hubungan dari judul dan tujuan penelitian. Bagian V adalah Referensi yang menejelaskan mengenai sumber kutipan dari penelitian sebelumnya.

\section{METODE}

\subsection{Jenis Penelitian}

Penelitian ini menggunakan metode deskriptif dengan pendekatan kualitatif. Dimana metode ini bertujuan untuk mengungkapkan fakta berdasarkan fenomena yang terjadi. Pendekatan kualitatif Data yang didapat berasal dari klinik kecantikan XYZ.

\subsection{Metode Pengumpulan Data}

Pengumpulan data dalam penelitian ini menggunakan 3 metode, yaitu :

\section{a) Wawancara}

Wawancara merupakan pertemuan antara 2 atau lebih manusia yang membahas dan mendiskusikan suatu masalah. Dalam penelitian ini wawancara dilakukan dengan seorang dokter di klinik kecantikan XYZ untuk mendapatkan data-data yang diperlukan.

b) Observasi

Metode observasi dilakukan peneliti pada klinik kecantikan XYZ untuk mendapatkan data mengenai detail proses bisnis atau teknik diagnosa yang dilakukan oleh dokter terhadap pasien.

c) Studi Literatur

Studi literatur digunakan untuk mendapatkan data-data primer maupun sekunder dari penelitian terkait melalui buku, penelitian ilmiah, jurnal maupun berita yang bersifat electronic dan nonelectronic.

\subsection{Tahapan Penelitian}

Extreme programming merupakan salah satu metode pengembangan turunan dari metode agile dan memiliki 4 tahapan utama yaitu Planning, Design, Coding dan Testing seperti yang tertera pada gambar 1 dibawah ini :

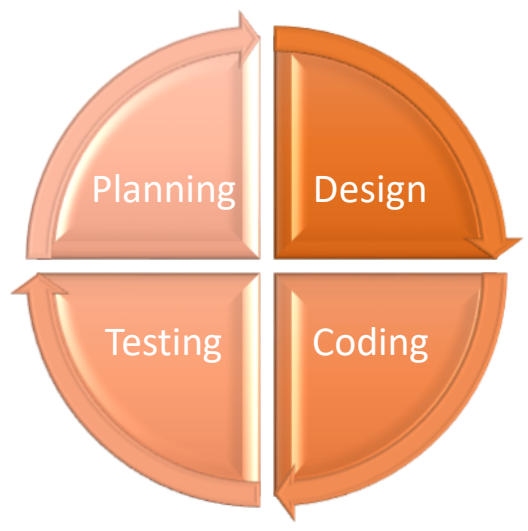

Gambar 1. Tahapan Extreme Programming

1) Planning

Secara sederhana, tahapan planning adalah tahapan diskusi antara customer dan developer, bisa juga disebut kedalam tahapan identifikasi kebutuhan dan analisa masalah. Pada tahap ini, penulis melakukan melakukan wawancara dengan pakar untuk menentukan kaidah dan data yang dibutuhkan dalam pembangunan sistem pakar. Secara umum Sistem Pakar (Expert System) adalah sebuah sistem yang dibuat atau dilatih untuk mempelajari pengetahuan dari seorang pakar atau manusia agar dapat menyelesaikan masalah berdasarkan pengetahuan tersebut [4].

\section{2) Design}

Setelah melakukan tahapan pertama, kemudian data-data dijabarkan dalam bentuk object oriented. Pada tahap ini penulis mulai melakukan perancangan dalam bentuk diagram-diagram UML.

\section{3) Coding}

Setelah membentuk rancangan, tahapan selanjutnya adalah coding. Pembuatan sistem dari rancangan mulai dikodekan ke dalam bentuk sistem dengan menggunakan bahasa pemrograman PHP, database PHP MySQL dan menggunakan server lokal XAMPP. XAMPP adalah sebuah bundel installer yang berisi satu paket Apache, PHP, dan MySQL untuk Windows [5]. PHP (Hypertext Preprocessor) adalah bahasa atau skrip yang sering diinputkan dan disisipkan didalam teks html yang biasanya berjalan di server, dan mampu membuat tampilan website lebih dinamis karena $P H P$ dapat memparsing kode dengan ekstensi .php [6] sementara MySQL merupakan database management systems yang saling berhubungan satu sama lain [7].

\section{4) Testing}

Tahap terakhir dalam metode ini adalah testing. Testing umumnya dapat dilakukan dengan 2 cara, yaitu White-Box Testing dan Black-Box Testing. White-Box Testing adalah salah satu metode pengujian yang dilakukan pada tingkat alur perangkat lunak [8], sementara Black-Box Testing adalah pengujian yang dilakukan dari sisi klien dengan melakukan percobaan fungsi dari aplikasi maupun sistem yang dibuat [9]. Kedua penngujian tersebut memiliki kelebihan dan kekurangan, 
namun tetap berdasar pada kebutuhan utama sistem yang dibangun.

\subsection{Perancangan Sistem}

\subsubsection{Flowchart}

Flowchart merupakan sebuah cara dalam mendeskripsikan tahapan sistem dalam memecahkan masalah dalam bentuk bagan yang menggunakan simbol tertentu [10]. Flowchart dari sistem yang dibangun dalam penelitian ini dijelaskan pada gambar 2 dibawah :

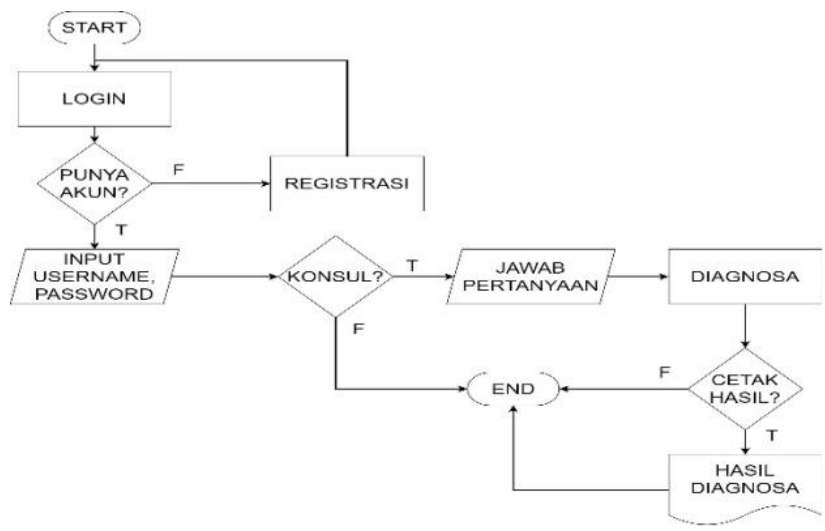

Gambar 2. Flowchart Sistem Pengguna

\subsubsection{Unified Modeling Language (UML)}

Unified Modeling Language (UML) adalah standar spesifikasi yang biasa digunakan dalam pendokumentasian sebuah sistem yang dibangun dan juga merupakan metodologi dalam mengembangkan suatu sistem yang berorientasi objek [11].

\section{a. Use Case Diagram}

Use Case dapat diartikan sebuah diagram yang digunakan untuk mendeklarasikan fungsi-fungsi tertentu dari sistem baik berupa komponen, aksi maupun kelas [12].

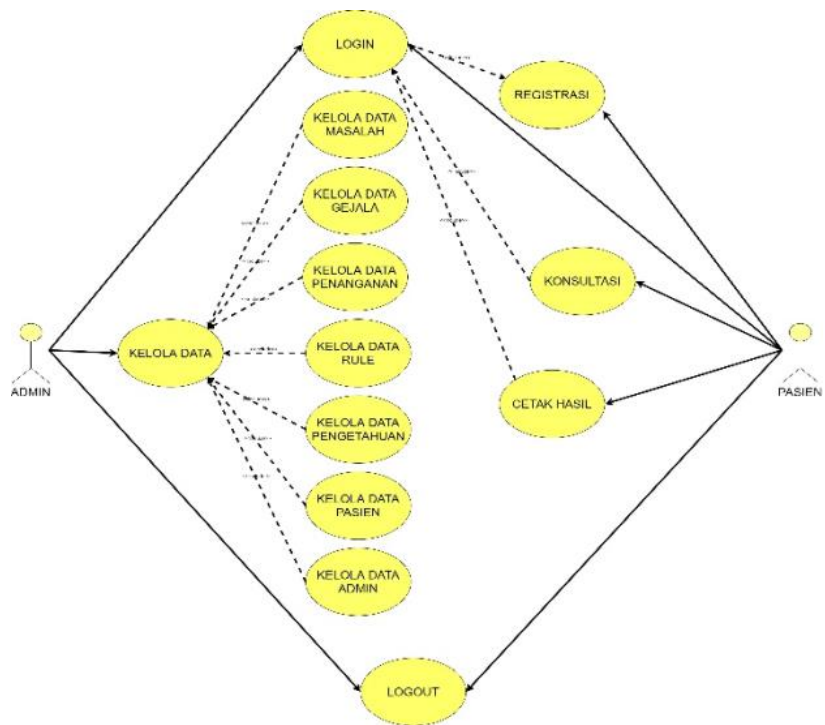

Gambar 3. Use Case Diagram Sistem

b. Activity Diagram

Activity Diagram adalah sebuah teknik penjabaran dari alur sistem yang memungkinkan pengguna mengetahui proses bisnis dari sistem tersebut [13] .

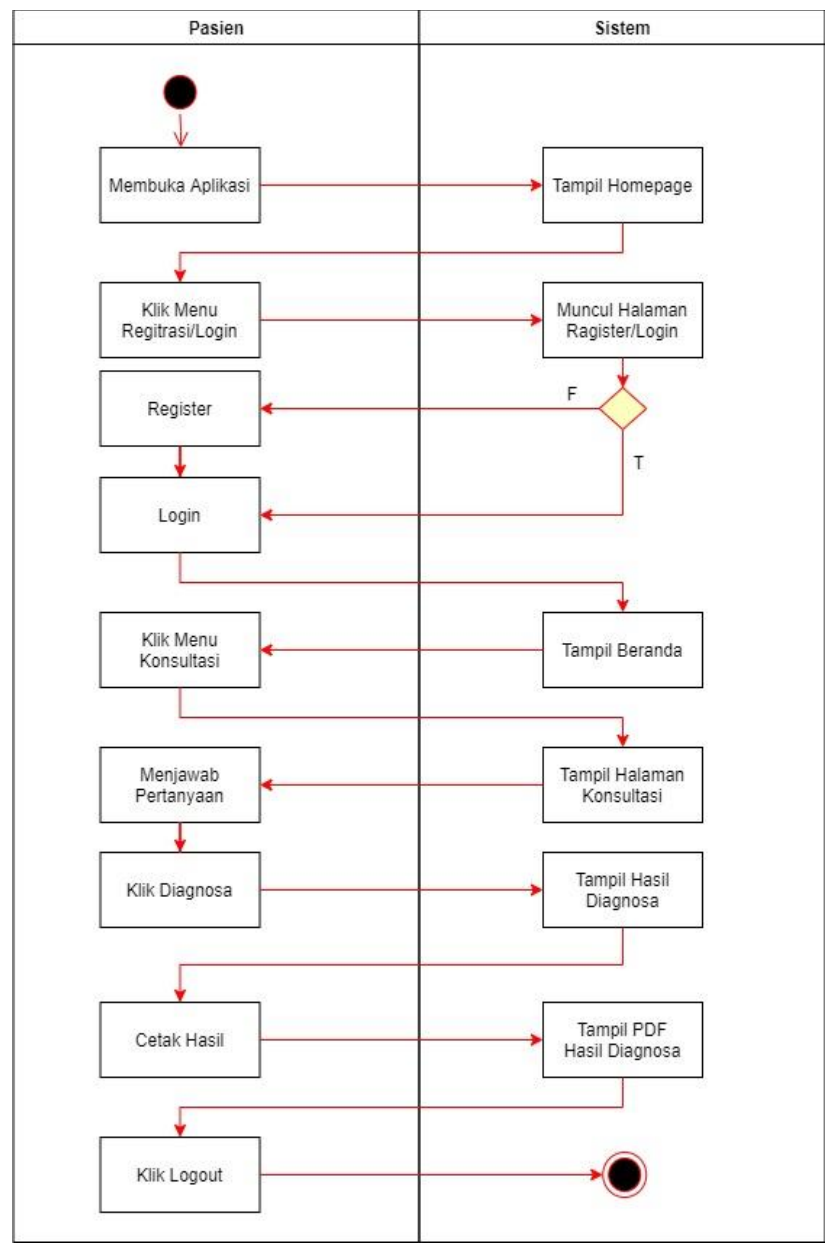

Gambar 4. Activity Diagram Sistem

\section{c. Sequence Diagram}

Sequence Diagram adalah satu dari beberapa diagram yang memiliki fungsi untuk menjabarkan mengenai hubungan dinamis antar objek di dalam sistem [14].

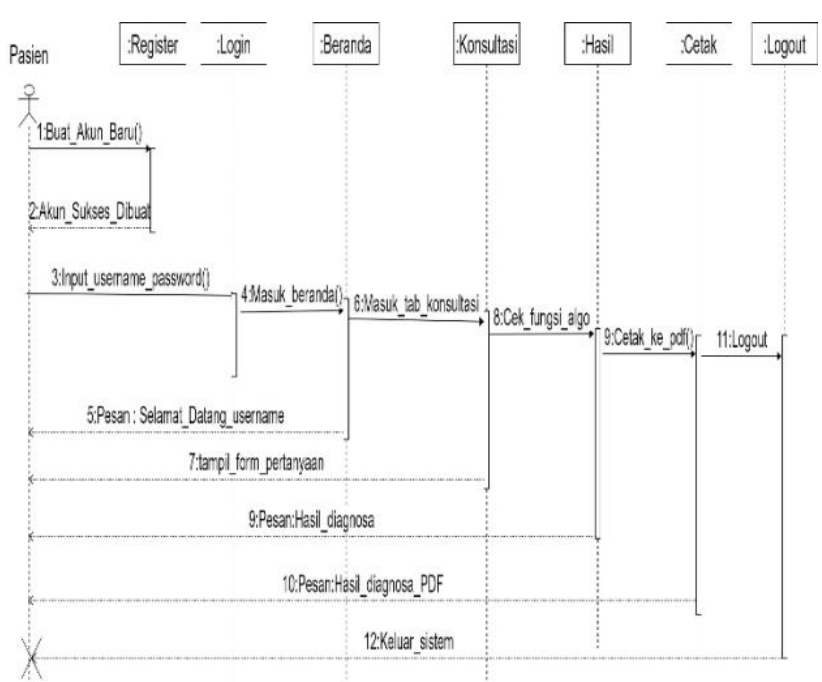

Gambar 5. Sequence Diagram

\section{d. Class Diagram}

Class Diagram adalah sebuah diagram yang menjelaskan mengenai kelas-kelas yang terdapat di dalam sistem yan dibangun [15]. 


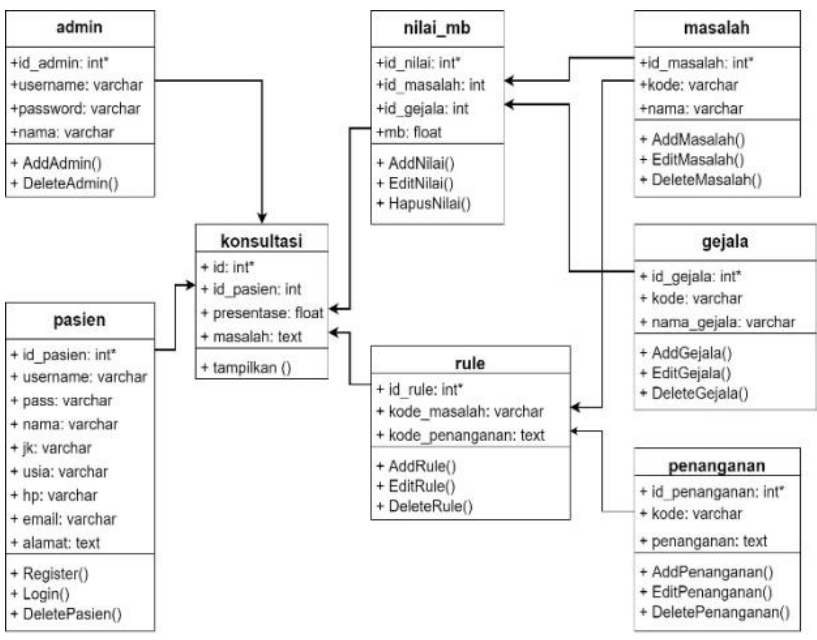

Gambar 6. Class Diagram

\subsection{Forward Chaining}

Forward Chaining adalah suatu metode yang menggunakan himpunan aturan kondisi-aksi dan bekerja berdasarkan kaidah yang dibuat berdasarkan aturan IF-THEN, kemudian proses diulang sampai ditemukan suatu hasil [16]. Pada inferensinya penelusuran akan diawali dari anteseden yaitu masalah yang dihadapi, kemudian menyimpulkan informasi dari serangkaian konsekuensi berupa irisan permasalahan dengan penyebab dan perbaikannya [17].

Didalam sistem yang dibangun, algoritma Forward Chaining diterapkan dalam menentukan masalah berdasarkan gejala yang dipilih dan solusi dari masalah tersebut. Pada algoritma Forward Chaining dikenal istilah kaidah atau aturan yang dibuat berdasarkan pengetahuan pakar. Untuk membuat kaidah atau aturan tersebut, diperlukan pembuatan tabel agar data dapat dibaca dengan baik. Masalah kulit dijelaskan pada Tabel 1, dimana terdapat 14 masalah kulit wajah dengan kodenya. Data ini dipilih berdasarkan masalah yang dapat ditangani dengan perawatan yang ada di klinik kecantikan XYZ.

Table 1. Masalah

\begin{tabular}{ll}
\hline Kode & Nama Masalah \\
Masalah & \\
\hline KM1 & Whiteheads \\
KM2 & Blackheads \\
KM3 & Jerawat Papula \\
KM4 & Jerawat Pustula \\
KM5 & Jerawat Nodula \\
KM6 & Jerawat Cystic \\
KM7 & Beruntusan \\
KM8 & Bekas Jerawat Ice Pick Scars \\
KM9 & Bekas Jerawat Boxed Scars \\
KM10 & Bekas Jerawat Hypertropic Scars \\
KM11 & Bekas Jerawat PIH \\
KM12 & Kulit Kusam \\
KM13 & Penuaan Dini \\
KM14 & Kulit Sehat \\
\hline
\end{tabular}

Kemudian Tabel 2 berikut ini menjelaskan mengenai gejala dari masalah kulit yang dijelaskan pada tabel 1 diatas. Beberapa masalah kulit memiliki gejala yang relatif umum, pada kasus ini gejala yang diinputkan kedalam sistem hanya cukup 1. Data pada
Tabel 2 didapatkan dari proses wawancara dan diskusi yang dilakukan bersama dokter di klinik kecantikan XYZ.

Tabel 2. Gejala

\begin{tabular}{|c|c|}
\hline $\begin{array}{l}\text { Kode } \\
\text { Gejala }\end{array}$ & Nama Gejala \\
\hline KG1 & Kulit Berminyak \\
\hline KG2 & Kulit Kering \\
\hline KG3 & Kulit Normal \\
\hline KG4 & Kulit Kombinasi \\
\hline KG5 & Kulit Sensitif \\
\hline KG6 & Tekstur Kulit Kasar \\
\hline KG7 & Tekstur Kulit Halus \\
\hline KG8 & Kulit Berjerawat \\
\hline KG9 & Benjolan Berukuran Kecil \\
\hline KG10 & Benjolan Berukuran Sedang \\
\hline KG11 & Benjolan Berukuran Besar \\
\hline KG12 & Sering Terpapapr Sinar Matahari \\
\hline KG13 & Benjolan Memiliki Puncak Lemak \\
\hline KG14 & Benjolan Memiliki Puncak Nanah \\
\hline KG15 & Benjolan Tidak Memiliki Puncak \\
\hline KG16 & Benjolan Bernanah Ketika Matang \\
\hline KG17 & Benjolan Berwarna Merah Meradang \\
\hline KG18 & Benjolan Bertahan Lebih Dari 3 Hari \\
\hline KG19 & $\begin{array}{l}\text { Benjolan Berwarna Putih Datar Didalam Pori- } \\
\text { pori }\end{array}$ \\
\hline KG20 & $\begin{array}{l}\text { Benjolan Berwarna Hitam Datar Didalam Pori- } \\
\text { pori }\end{array}$ \\
\hline KG21 & Benjolan Terasa Keras dan Padat \\
\hline KG22 & Benjolan Berada Dibawah Lapisan Kulit \\
\hline KG23 & $\begin{array}{l}\text { Benjolan Mucul Dalam Julah Banyak dan } \\
\text { Menyebar }\end{array}$ \\
\hline KG24 & Pori-pori Terlihat \\
\hline KG25 & Pori-pori Tertutup \\
\hline KG26 & Sakit Ketika Disentuh \\
\hline KG27 & Area Kulit Terasa Kencang \\
\hline KG28 & Adanya Peradangan Kulit \\
\hline KG29 & Terdapat Bekas Jerawat \\
\hline KG30 & Bekas Jerawat Lebih Rendah Dari Kulit Wajah \\
\hline KG31 & $\begin{array}{l}\text { Bekas Jerawat Nampak Seperti Lubang Kecil } \\
\text { Yang Dalam }\end{array}$ \\
\hline KG32 & $\begin{array}{l}\text { Bekas Jerawat Berupa Lubang Berbentuk Box } \\
\text { dan Tidak Terlalu Dalam }\end{array}$ \\
\hline KG33 & Bekas Jerawat Lebih Tinggi Dari Kulit Wajah \\
\hline KG34 & $\begin{array}{l}\text { Bekas Jerawat Nampak Seperti Keloid Menyebar } \\
\text { di Satu Area }\end{array}$ \\
\hline KG35 & $\begin{array}{l}\text { Bekas Jerawat Berwarna } \\
\text { Coklat/Merah/Pink/Hitam }\end{array}$ \\
\hline KG36 & Struktur Kulit Rata \\
\hline KG37 & Struktur Kulit Tidak Rata \\
\hline KG38 & Warna Kulit Tidak Merata \\
\hline KG39 & Terdapat Kerutan dan Garis Halus \\
\hline KG40 & Terdapat Flek Hitam atau Coklat \\
\hline KG41 & Kulit Kendur \\
\hline KG42 & Volume Wajah Terkesan Berkurang \\
\hline KG43 & Kadar Kelembapan Normal \\
\hline KG44 & Warna Kulit Merata \\
\hline
\end{tabular}

Tabel 3 dibawah ini menjelaskan nama penanganan dari masalah kulit dan kodenya. Data penanganan yang dipilih pada Tabel 3 merupakan metode atau treatment yang terdapat pada klinik kecantikan XYZ. 
Tabel 3. Penanganan

\begin{tabular}{ll}
\hline $\begin{array}{l}\text { Kode } \\
\text { Penanganan }\end{array}$ & Nama Penanganan \\
\hline S01 & Facial With Natural Extract Charcoal \\
S02 & Regular Peeling \\
S03 & Facial with Natural Extarct Tea Tree \\
S04 & Regular Facial Acne \\
S05 & Detox Facial \\
S06 & Blue Light Therapy \\
S07 & Regular Facial Acne \\
S08 & Laser Treatment \\
S09 & Punch out Excision \\
S10 & Electro cauter \\
S11 & Chemical Peeling \\
S12 & Peeling Whitening \\
S13 & Oxy Facial \\
S14 & Meso Therapy \\
S15 & Anti Aging \\
S16 & Diamond Microdebarmasi \\
S17 & Facial with Natural Extarct Milk and Peralh \\
& Shine \\
S18 & Regular Facial Whitening \\
\hline
\end{tabular}

\section{Kaidah Forward Chaining}

Berikut adalah aturan dalam menentukan masalah kulit wajah dan solusi perawatannya berdasarkan data gejala yan dijelaskan pada Tabel 1, kemudian data masalah pada Tabel 2 dan data solusi perawatan pada Tabel 3 :

Aturan 1

IF (KG1,KG2,KG4,KG6,KG12,KG19,KG24) THEN KM1

IF KM1 THEN S01

Aturan 2

IF (KG1,KG2,KG4,KG6,KG12,KG19,KG24) THEN KM1

IF KM1 THEN S01

Aturan 3

IF (KG1,KG6,KG9,KG15,KG17,KG26) THEN KM3

IF KM3 THEN S03

Aturan 4

IF (KG1,KG6,KG10,KG14,KG17,KG26) THEN KM4

IF KM4 THEN S04

Aturan 5

IF

(KG1,KG2,KG5,KG11,KG15,KG18,KG21,KG22,KG26,KG27, KG28) THEN KM5

IF KM5 THEN S05

Aturan 6

IF (KG1,KG6,KG11,KG15,KG17,KG18,KG21,KG26) THEN KM6

IF KM6 THEN S06

Aturan 7

IF (KG2,KG4,KG5,KG9,KG13,KG23,KG28) THEN KM7

IF KM7 THEN S07

Aturan 8

IF (KG30,KG31,KG37) THEN KM8

IF KM8 THEN S08

Aturan 9

IF (KG30,KG32,KG37) THEN KM9

IF KM9 THEN S09

Aturan 10

IF (KG33,KG34,KG37) THEN KM10

IF KM10 THEN S10
Aturan 11

IF (KG7,KG35,KG36) THEN KM11

IF KM11 THEN S11

Aturan 12

IF (KG2, KG38, KG39,KG40) THEN KM12

IF KM12 THEN (S12,S13,S18)

Aturan 13

IF (KG39,KG40,KG41,KG42) THEN KM13

IF KM13 THEN (S14,S15,S16)

Aturan 14

IF (KG3,KG7,KG43,KG44) THEN KM14

IF KM14 THEN S17

\subsection{Certainty Factor}

Certainty Factor merupakan metode yang biasa digunakan dalam menentukan suatu permassalahan yang memiliki jawaban belum pasti atau samar [18]. Metode ini memerlukan 2 nilai utama dalam perhitungannya, yaitu nilai MB (Measurement of Beliefe) dan MD (Measurement of Disbeliefe). Algoritma Certainty Factor dalam sistem digunakan untuk menghitung derajat keyakinan dari keputusan yang diambil. Pada sistem presentasi tertinggi dari perhitungan akan menjadi diagnosa dari masalah kulit yang dialami. Persamaan umum yang digunakan dalam notasinya adalah [19] :

$C F(h, e)=M B(h, e)-M D(h, e)$

Dimana :

Cf $(h, e):$ Faktor Kepastian

$\mathrm{MB}(\mathrm{h}, \mathrm{e})$ : tingkat kepercayaan terhadap hipotesis $\mathrm{H}$ jika diberikan evidence $\mathrm{e}$.

$\mathrm{MD}(\mathrm{h}, \mathrm{e})$ : tingkat ketidakpercayaan terhadap evidence $\mathrm{h}$ jika diberikan evidence e.

Dalam implementasinya, perhitungan nilai CF menggunakan perhitungan dengan $\mathrm{CF}$ Sekuensial. Dimanna Nilai CF Sekuensial ini memerlukan nilai CF pakar dalam perhitungannya. Sesuai dengan persamaan yang dijabarkan pada persamaan (3). Nilai CF Pakar sendiri merupakan nilai derajat keyakinan dari seorang pakar terhadap suatu gejala dari masalah. Tabel 4 dibawah ini menjelaskan mengenai pembobotan nilai MB pakar yang diinputkan kedalam sistem :

Tabel 4. Nilai CF Pakar

\begin{tabular}{lll}
\hline Nama Masalah & Gejala & $\begin{array}{l}\text { Nilai MB } \\
\text { Pakar }\end{array}$ \\
\hline Whiteheads & Kulit berminyak & 0,6 \\
& Sering terpapar sinar & 0,4 \\
& matahari & \\
& Benjolan putih datar di & 0.8 \\
& dalam pori-pori & \\
& Pori-pori terlihat & 0,8 \\
& Tekstur kulit kasar & 0,2 \\
& Kulit kombinasi & 0,8 \\
Blackheads & Kulit kering & 0.4 \\
& Benjolan hitam datar di & 0,8 \\
& dalam pori-pori & \\
& Pori-pori terlihat & 0,6 \\
& Kulit kombinasi & 0,6 \\
Jerawat Papula & Kulit berminyak & 0,6
\end{tabular}




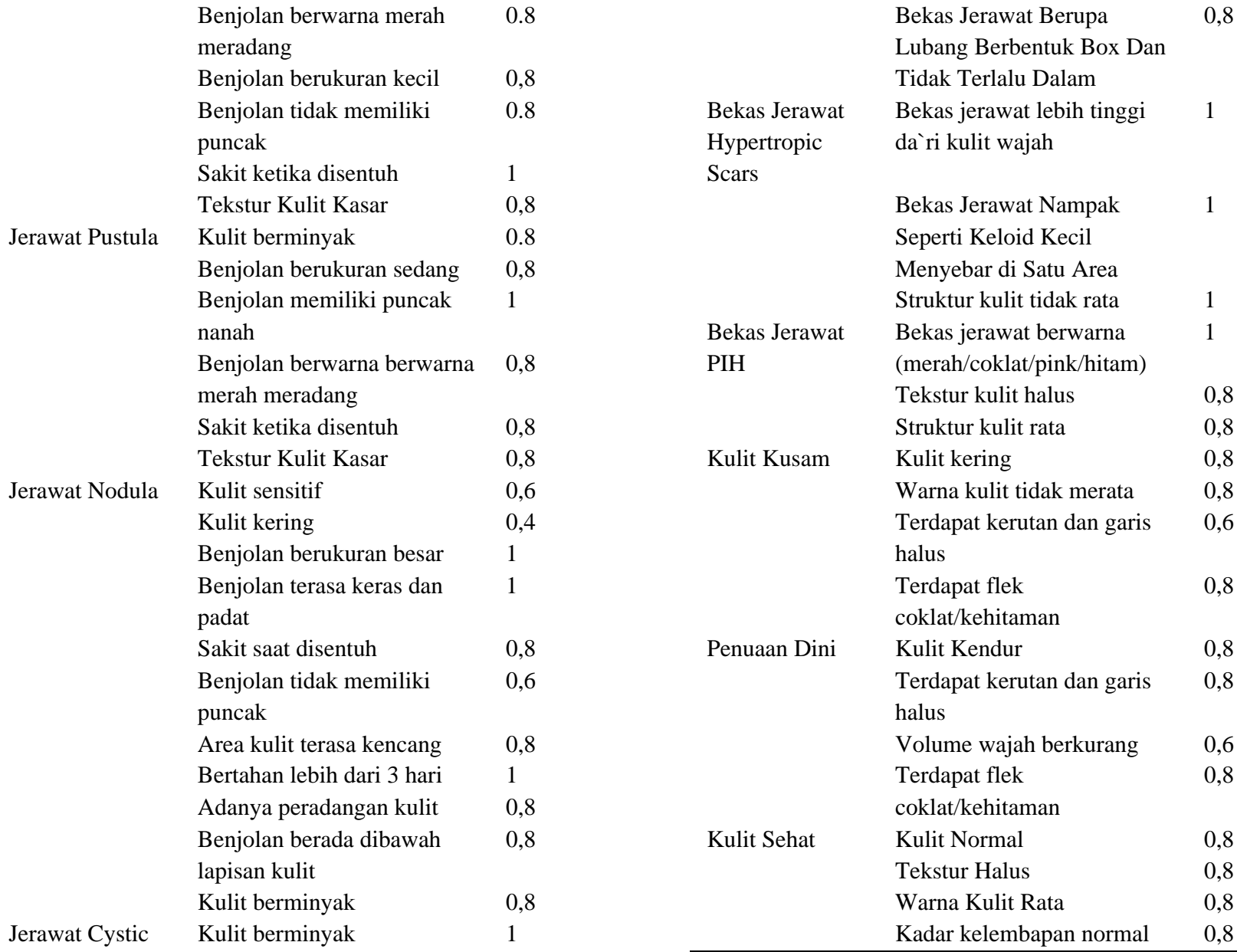

Benjolan berwarna merah $\quad 0,8$

meradang

Benjolan terasa keras dan $\quad 0,6$

padat

Sakit ketika disentuh $\quad 0,8$

Benjolan berukuran besar 1

Benjolan tidak memiliki $\quad 0,8$

puncak

Benjolan bernanah ketika $\quad 0,6$

matang

Tekstur Kulit kasar $\quad 0,8$

Beruntusan Kulit Sensitif 1

Kulit kombinasi $\quad 0.8$

Benjolan berukuran kecil $\quad 0,8$

Benjolan muncul dalam $\quad 0,8$

jumlah banyak dan

menyebar

Benjolan puncak berisi

lemak

Adanya peradangan kulit 1

Kulit kering $\quad 0,6$

Bekas Jerawat Bekas Jerawat lebih rendah 1

Ice pick Scars dari kulit wajah

Struktur kulit tidak rata $\quad 0,8$

Bekas jerawat nampak $\quad 0,8$

seperti lubang kecil yang

dalam

Bekas Jerawat Bekas Jerawat lebih rendah 1

Boxed Scars dari kulit wajah

Struktur kulit tidak rata
Bekas Jerawat Berupa

Tidak Terlalu Dalam

Bekas jerawat lebih tingg

1

1

Seperti Keloid Kecil

Menyebar di Satu Area

0,8

0,8

0,8

0,8

0,6

0,8

0,8

0,6

0,8

0,8

$\begin{array}{ll}\text { Warna Kulit Rata } & 0,8 \\ \text { Kadar kelembapan normal } & 0,8\end{array}$

\section{Penentuan CF Paralel}

CF Paralel merupakan nilai CF yang diperoleh dari beberapa premis pada sebuah aturan. Besarnya $\mathrm{CF}$ sekuensial dipengaruhi oleh CF User untuk masing-masing premis dan operator dari premis [20]. Penentuan nilai ini dapat dilakukan dengan pembobotan pada setiap premis, dalam penelitian ini dapat dilihat pada Tabel 5 :

Tabel 5. Pembobotan Nilai CF User

\begin{tabular}{ll}
\hline Bobot & Keterangan \\
\hline 1 & Sangat yakin \\
0,8 & Yakin \\
0,6 & Cukup Yakin \\
0,4 & Sedikit Yakin \\
0,2 & Kurang Yakin \\
0 & Tidak \\
\hline
\end{tabular}

\section{Penentuan CF Sekuensial}

CF sekuensial diperoleh dari perhitungan antara CF Paralel dari semua premis dengan $\mathrm{CF}$ yang diberikan oleh pakar. Persamaan untuk menghitung CF Sekuensial dapat dilihat pada persamaan 2 berikut :

$C F(x, y)=C F(x) \times C F(y)$

Dimana :

$\mathrm{CF}(\mathrm{x}, \mathrm{y})$ : Nilai CF Paralel.

$\mathrm{CF}(\mathrm{x})$ : Nilai CF Sekuensial dari semua premis.

$\mathrm{CF}(\mathrm{y})$ : Nilai CF Pakar 


\section{Penentuan CF Combine}

Langkah selanjutnya adalah menghitung nilai CF Combine. Nilai ini digunakan untuk menghitung seberapa besar presentase akurasi dari kesimpulan yang akan dibuat. Rumus untuk mengitung CF Combine adalah pada persamaan berikut [3] :

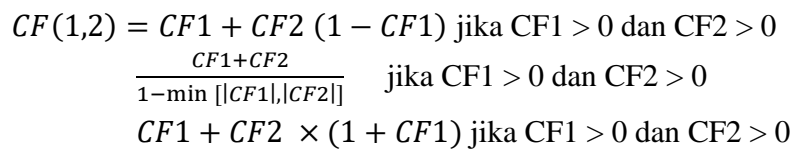

(3)

Untuk menghitung CFCombine secara manual, perlu dilakukan perhitungan secara keseluruhan terhadap setiap gejala yang dipilih dan merujuk pada masalah kulit apa. Karena beberapa masalah kulit wajah memiliki gejala yang relatif umum, maka dari itu perhitungan harus dilakukan pada setiap masalah yang ada.

\section{Menghitung Akurasi}

Setelah Menemukan nilai CFCombine untuk setiap gejala terpilih dari sebuah masalah kulit, langkah terakhir adalah melakukan perhitungan akurasi dengan rumus :

Akurasi $=$ CFCom $\times 100 \%$

Nilai ini kemudian akan menjadi dasar sistem dalam memutuskan masalah kulit pasien dengan mengambil nilai presentasi terbesar. Dan memberikan solusi berdasarkan aturan atau kaidah dari algoritma forward chaining.

\section{Batasan Masalah}

Batasan masalah digunakan untuk menjelaskan fokus dari penelitian yang dilakukan. Dalam penelitian ini batasan masalah yang digunakan adalah :

1. Sistem yang dibangun berbasis web dengan menggunakan bahasa pemrograman PHP dan database lokal.

2. Data yang digunakan dalam penelitian didapatkan melalui wawancara dan diskusi dengan dokter di klinik kecantikan XYZ. 3. Sistem hanya dibuat untuk mendeteksi masalah kulit wajah.

4. Data uji dilakukan secara acak pada masyarakat sekitar dengan batasan usia antara 16 - 50 tahun tanpa memperhatikan jenis kelamin.

\section{HASIL DAN PEMBAHASAN}

Berdasarkan pengujian yang dilakukan pada sistem, salah satu kasus user memilih gejala seperti yang ditampilkan pada Tabel 6 Berikut :

Tabel 6. Gejala Yang Dipilih User

\begin{tabular}{lll}
\hline $\begin{array}{l}\text { Kode } \\
\text { Gejela }\end{array}$ & Nama Gejala & MD User \\
\hline KG1 & Kulit berminyak & Cukup Yakin \\
KG10 & Benjolan Berukuran Sedang & Cukup Yakin \\
KG14 & Benjolan Memiliki Puncak & Cukup Yakin \\
& Nanah & \\
KG17 & Benjolan Berwarna Merah & Sedikit Yakin \\
& Meradang & \\
KG6 & Tekstur Kulit Kasar & Yakin \\
\hline
\end{tabular}

14 Bunga Ratna Sari
Dari data diatas maka sistem sudah mendapatkan nilai MD User yang akan digunakan dalam perhitungan nilai CF. Sistem yang dibangun diharapkan dapat memberikan nilai akurasi yang sama dengan perhitungan $\mathrm{CF}$ manual. Berikut adalah perhitungan nilai CF untuk untuk setiap kemungkinan dari diagnosa masalah kulit berdasarkan gejala yang dipilih di Tabel 6 :

1. Whiteheads

Tabel 7 dibawah ini menjelaskan perhitungan nilai $\mathrm{CF}(\mathrm{h}, \mathrm{e})$ untuk masalah kulit whiteheads.

Tabel 7. Perhitungan Nilai CF (h,e) untuk Whiteheads

\begin{tabular}{|c|c|c|c|c|c|}
\hline Kode & \multirow{2}{*}{\multicolumn{2}{|c|}{ Nama Gejala }} & MD & MB & $\mathrm{CF}$ \\
\hline Gejala & & & User & Pakar & $(\mathrm{h}, \mathrm{e})$ \\
\hline KG1 & \multicolumn{2}{|c|}{ Kulit berminyak } & 0.6 & 0.6 & 0.36 \\
\hline KG10 & $\begin{array}{l}\text { Benjolan } \\
\text { Sedang }\end{array}$ & Berukuran & 0.6 & 0 & 0 \\
\hline KG14 & $\begin{array}{l}\text { Benjolan } \\
\text { Puncak N }\end{array}$ & Memiliki & 0.6 & 0 & 0 \\
\hline KG17 & \multicolumn{2}{|c|}{$\begin{array}{l}\text { Benjolan Berwarna Merah } \\
\text { Meradang }\end{array}$} & 0.4 & 0 & 0 \\
\hline KG6 & \multicolumn{2}{|c|}{ Tekstur Kulit Kasar } & 0.8 & 0.2 & 0.16 \\
\hline
\end{tabular}

Setelah menemukan nilai $\mathrm{CF}(\mathrm{h}, \mathrm{e})$, maka dilakukanlah perhitungan nilai CFcombine sebagai berikut :

$$
\begin{aligned}
& \text { a. } \mathrm{CF}(1,2)=\mathrm{CF} 1+(\mathrm{CF} 2 *(1-\mathrm{CF} 1)) \\
& =0,36+(0 *(1-0,36)=0,36 \text { CFold } \\
& \text { b. } \mathrm{CF}(\text { old }, 3)=\mathrm{CFold}+(\mathrm{CF} 3 *(1-\mathrm{CFold})) \\
& =0,36+(0 *(1-0,36))=0,36 \text { CFold } \\
& \text { c. } \mathrm{CF}(\text { old }, 4)=\mathrm{CFold}+(\mathrm{CF} 4 *(1-\mathrm{CFold})) \\
& =0,36+(0 *(1-0,36))=0,36 \text { CFold } \\
& \text { d. } \mathrm{CF}(\text { old }, 5)=\text { CFold }+(\text { CF5 * }(1-\text { CFold })) \\
& =0,36+(0,16 *(1-0,36))=0,4624 \text { CFold }
\end{aligned}
$$

\begin{tabular}{|c|c|c|c|c|c|}
\hline $\begin{array}{l}\text { Kode } \\
\text { Gejala }\end{array}$ & \multicolumn{2}{|c|}{ Nama Gejala } & $\begin{array}{l}\text { MD } \\
\text { User }\end{array}$ & $\begin{array}{l}\text { MB } \\
\text { Pakar }\end{array}$ & $\begin{array}{l}\text { CF } \\
(\mathrm{h}, \mathrm{e})\end{array}$ \\
\hline KG1 & \multicolumn{2}{|c|}{ Kulit berminyak } & 0.6 & 0.6 & 0.36 \\
\hline KG10 & $\begin{array}{l}\text { Benjolan } \\
\text { Sedang }\end{array}$ & Berukuran & 0.6 & 0 & 0 \\
\hline KG14 & \multicolumn{4}{|c|}{ Puncak Nanah } & 0 \\
\hline KG17 & \multicolumn{2}{|c|}{$\begin{array}{l}\text { Benjolan Berwarna Merah } \\
\text { Meradang }\end{array}$} & 0.4 & 0.8 & 0.32 \\
\hline KG6 & \multicolumn{2}{|c|}{ Tekstur Kulit Kasar } & 0.8 & 0.8 & 0.64 \\
\hline
\end{tabular}

Akurasi : CFold $* 100 \%=0,4624 * 100 \%=46,24 \%$

2. Jerawat Papula

Tabel 8 dibawah ini menjelaskan perhitungan nilai $\mathrm{CF}(\mathrm{h}, \mathrm{e})$ untuk masalah kulit jerawat papula.

Tabel 8. Perhitungan Nilai CF (h,e) untuk Jerawat Papula

Setelah menemukan nilai $\mathrm{CF}(\mathrm{h}, \mathrm{e})$, maka dilakukanlah perhitungan nilai CFcombine sebagai berikut : 


\begin{tabular}{|c|c|c|c|c|c|}
\hline \multicolumn{6}{|c|}{ a. $\begin{aligned} \mathrm{CF}(1,2) & =\mathrm{CF} 1+(\mathrm{CF} 2 *(1-\mathrm{CF} 1)) \\
& =0,36+(0 *(1-0,36)=0,36 \text { CFold }\end{aligned}$} \\
\hline \multicolumn{6}{|c|}{ b. $\mathrm{CF}($ old, 3$)=\mathrm{CFold}+(\mathrm{CF} 3 *(1-$ Cfold $))$} \\
\hline \multicolumn{6}{|c|}{ c. $\mathrm{CF}($ old, 4$)=\mathrm{CFold}+(\mathrm{CF} 4 *(1-$ Cfold $))$} \\
\hline \multicolumn{6}{|c|}{ d. $\begin{aligned} \mathrm{CF}(\text { old }, 5) & =\text { CFold }+(\text { CF5 } *(1-\text { Cfold })) \\
& =0,5648+(0,64 *(1-0,5648))=0,8433 \text { CFold }\end{aligned}$} \\
\hline \multicolumn{6}{|c|}{ Akurasi : CFold $* 100 \%=0,8433 * 100 \%=84,33 \%$} \\
\hline \multicolumn{6}{|c|}{ 3. Jerawat Pustula } \\
\hline \multicolumn{6}{|c|}{$\begin{array}{l}\text { Tabel } 9 \text { dibawah ini menjelaskan perhitungan nilai } \mathrm{CF}(\mathrm{h}, \mathrm{e}) \text { untuk } \\
\text { masalah kulit jerawat pustula. }\end{array}$} \\
\hline \multicolumn{6}{|c|}{ Tabel 9. Perhitungan Nilai CF (h,e) untuk Jerawat Pustula } \\
\hline $\begin{array}{l}\text { Kode } \\
\text { Gejala }\end{array}$ & Nama Gej & & $\begin{array}{l}\text { MD } \\
\text { User }\end{array}$ & $\begin{array}{l}\text { MB } \\
\text { Pakar }\end{array}$ & $\begin{array}{l}\mathrm{CF} \\
(\mathrm{h}, \mathrm{e})\end{array}$ \\
\hline KG1 & Kulit bern & & 0.6 & 0.8 & 0.48 \\
\hline KG10 & $\begin{array}{l}\text { Benjolan } \\
\text { Sedang }\end{array}$ & Berukuran & 0.6 & 0.8 & 0.48 \\
\hline KG14 & $\begin{array}{l}\text { Benjolan } \\
\text { Puncak N }\end{array}$ & Memiliki & 0.6 & 1 & 0.6 \\
\hline KG17 & $\begin{array}{l}\text { Benjolan } \\
\text { Meradang }\end{array}$ & arna Merah & 0.4 & 0.8 & 0.32 \\
\hline KG6 & Tekstur K & Kasar & 0.8 & 0.8 & 0.64 \\
\hline
\end{tabular}

Setelah menemukan nilai $\mathrm{CF}(\mathrm{h}, \mathrm{e})$, maka dilakukanlah perhitungan nilai CFcombine sebagai berikut :

$$
\begin{aligned}
& \text { a. } \mathrm{CF}(1,2)=\mathrm{CF} 1+(\mathrm{CF} 2 *(1-\mathrm{CF} 1)) \\
& =0,48+(0,48 *(1-0,48)=0,7296 \text { CFold } \\
& \text { b. } \begin{aligned}
\mathrm{CF}(\text { old }, 3) & =\text { CFold }+(\mathrm{CF} 3 *(1-\mathrm{CFold})) \\
& =0,7296+(0,6 *(1-0,7296))=0,8918 \text { CFold }
\end{aligned} \\
& \text { c. } \mathrm{CF}(\text { old }, 4)=\mathrm{CFold}+(\mathrm{CF} 4 *(1-\mathrm{CFold})) \\
& =0,8918+(0,32 *(1-0,8918))=0,9264 \text { CFold } \\
& \text { d. } \mathrm{CF}(\text { old }, 5)=\text { CFold }+(\text { CF5 } *(1-\text { Cfold })) \\
& =0,9264+(0,64 *(1-0,9264))=0,9735 \text { CFold }
\end{aligned}
$$

Akurasi : CFold $* 100 \%=0,9735 * 100 \%=97,35 \%$

\section{Jerawat Nodula}

Tabel 10 dibawah ini menjelaskan perhitungan nilai $\mathrm{CF}(\mathrm{h}, \mathrm{e})$ untuk masalah kulit jerawat nodula.

Tabel 10. Perhitungan Nilai CF (h,e) untuk Jerawat Nodula

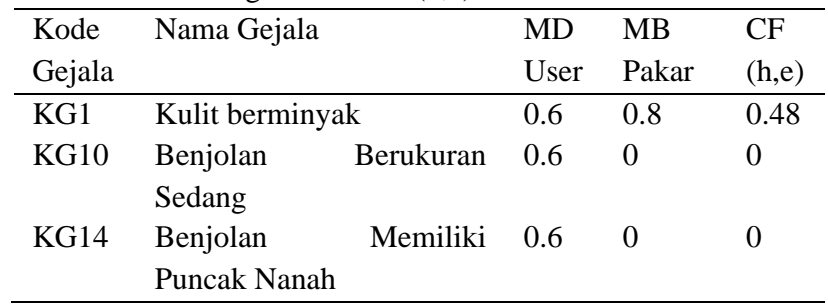

\begin{tabular}{lllll}
\hline KG17 & $\begin{array}{l}\text { Benjolan Berwarna Merah } \\
\text { Meradang }\end{array}$ & 0.4 & 0 & 0 \\
KG6 & Tekstur Kulit Kasar & 0.8 & 0 & 0 \\
\hline
\end{tabular}

Setelah menemukan nilai $\mathrm{CF}(\mathrm{h}, \mathrm{e})$, maka dilakukanlah perhitungan nilai CFcombine sebagai berikut :

\begin{tabular}{|c|c|c|c|c|c|}
\hline $\begin{array}{l}\text { Kode } \\
\text { Gejala }\end{array}$ & \multicolumn{2}{|c|}{ Nama Gejala } & $\begin{array}{l}\text { MD } \\
\text { User }\end{array}$ & $\begin{array}{l}\text { MB } \\
\text { Pakar }\end{array}$ & $\begin{array}{l}\text { CF } \\
(h, e)\end{array}$ \\
\hline KG1 & \multicolumn{2}{|c|}{ Kulit berminyak } & 0.6 & 1 & 0.6 \\
\hline KG10 & $\begin{array}{l}\text { Benjolan } \\
\text { Sedang }\end{array}$ & Berukuran & 0.6 & 0 & 0 \\
\hline KG14 & \multicolumn{2}{|c|}{ Puncak Nanah } & 0.6 & 0 & 0 \\
\hline KG17 & \multicolumn{2}{|c|}{$\begin{array}{l}\text { Benjolan Berwarna Merah } \\
\text { Meradang }\end{array}$} & 0.4 & 0.8 & 0.32 \\
\hline KG6 & \multicolumn{2}{|c|}{ Tekstur Kulit Kasar } & 0.8 & 0.8 & 0.64 \\
\hline
\end{tabular}

$$
\begin{aligned}
& \text { a. } \mathrm{CF}(1,2)=\mathrm{CF} 1+(\mathrm{CF} 2 *(1-\mathrm{CF} 1)) \\
& =0,48+(0 *(1-0,48)=0,48 \text { CFold } \\
& \text { b. } \mathrm{CF}(\text { old }, 3)=\mathrm{CFold}+(\mathrm{CF} 3 *(1-\mathrm{CFold})) \\
& =0,48+(0 *(1-0,48)=0,48 \text { CFold } \\
& \text { c. } \mathrm{CF}(\text { old }, 4)=\mathrm{CFold}+(\mathrm{CF} 4 *(1-\mathrm{CFold})) \\
& =0,48+(0 *(1-0,48)=0,48 \text { CFold } \\
& \text { d. CF(old,5) }=\text { CFold }+(\text { CF5 } *(1-\text { CFold })) \\
& =0,48+(0 *(1-0,48)=0,48 \text { CFold }
\end{aligned}
$$

Akurasi : CFold $* 100 \%=0,48 * 100 \%=48 \%$

\section{Jerawat Cystic}

Tabel 11 dibawah ini menjelaskan perhitungan nilai $\mathrm{CF}(\mathrm{h}, \mathrm{e})$ untuk masalah kulit jerawat Cystic.

Tabel 11. Perhitungan Nilai CF (h,e) untuk Jerawat Cystic

Setelah menemukan nilai $\mathrm{CF}(\mathrm{h}, \mathrm{e})$, maka dilakukanlah perhitungan nilai CFcombine sebagai berikut :

$$
\begin{aligned}
& \text { a. } \begin{aligned}
\mathrm{CF}(1,2) & =\mathrm{CF} 1+(\mathrm{CF} 2 *(1-\mathrm{CF} 1)) \\
& =0,6+(0 *(1-0,6)=0,6 \text { CFold }
\end{aligned} \\
& \begin{aligned}
\text { b. } \mathrm{CF}(\text { old }, 3) & =\mathrm{CFold}+(\mathrm{CF} 3 *(1-\mathrm{CF} \text { old })) \\
& =0,6+(0 *(1-0,6))=0,6 \text { CFold }
\end{aligned}
\end{aligned}
$$

$$
\begin{aligned}
\text { c. } \mathrm{CF}(\text { old }, 4) & =\text { CFold }+(\mathrm{CF} 4 *(1-\mathrm{CFold})) \\
& =0,6+(0,32 *(1-0,6))=0,728 \text { CFold } \\
\text { d. } \mathrm{CF}(\text { old }, 5) & =\text { CFold }+(\text { CF5 } *(1-\text { CFold })) \\
& =0,728+(0,64 *(1-0,728))=0,9020 \text { CFold }
\end{aligned}
$$

Akurasi : CFold $* 100 \%=0,9020 * 100 \%=90,20 \%$

Dengan perhitungan manual yang dilakukan diatas, akurasi tertinggi untuk gejala yang dipilih oleh user adalah user mengalami masalah jerawat pustula dengan tingkat akurasi sebesar 97,35\%. Pada implementasinya ke dalam sistem dengan menggunakan studi kasus yang sama menunjukkan besar nilai akurasi yang sama yaitu 97,35\% jerawat pustula dan memberikan 
solusi untuk melakukan Regular Facial Acne Treatment sesuai dengan kaidah forward chaining. Berikut gambar 3 adalah hasil implementasinya kedalam sistem.

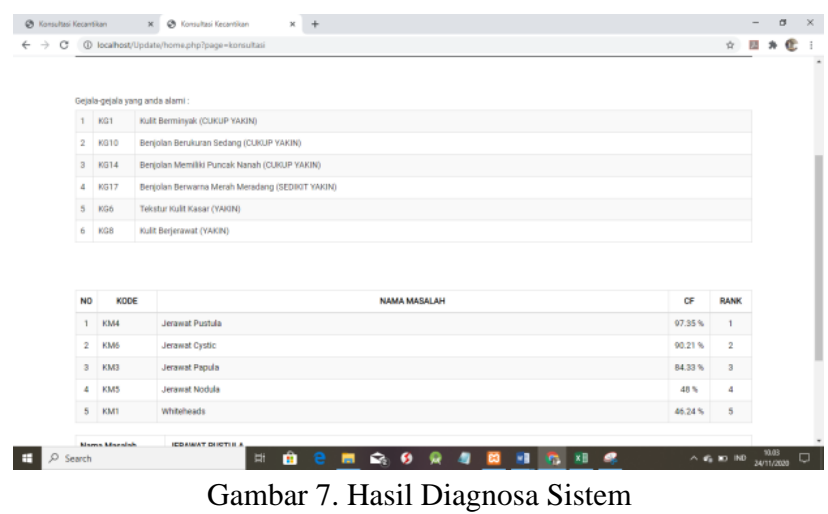

Pengujian sistem dilakukan dengan 40 data user yang menggunakan sistem yang telah dibangun. Responden tersebut terdiri dari 31 responden wanita dan 9 responden pria. Usia responden dibagi menjadi 3 golongan, yaitu :

1. Remaja : Usia 16-25 tahun.

2. Dewasa : Usia 26- 45 tahun.

3. Lansia : Usia 46-50 tahun.

Dari 40 data tersebut rata-rata akurasi yang didapatkan adalah sebesar $94,25 \%$, akurasi tertinggi mencapai $100 \%$ dengan jumlah 6 data, dan akurasi terendah sebesar 85,86\% dengan jumlah 3 data.

Tabel 12 dibawah ini menjelaskan mengenai pengujian fungsi sistem secara keseluruhan menggunakan metode Black-box Testing.

Tabel 12. Pengujian Fungsi Sistem

\begin{tabular}{|c|c|c|c|c|}
\hline No & Pengujian & $\begin{array}{l}\text { Hasil yang } \\
\text { Diharapkan }\end{array}$ & $\begin{array}{l}\text { Hasil } \\
\text { Pengujian }\end{array}$ & Ket. \\
\hline 1. & $\begin{array}{l}\text { Register } \\
\text { dan Login }\end{array}$ & $\begin{array}{l}\text { Menampilkan } \\
\text { Form Register } \\
\text { dan Login }\end{array}$ & $\begin{array}{l}\text { Tampil } \\
\text { Form } \\
\text { Register dan } \\
\text { Login }\end{array}$ & Valid \\
\hline 2. & $\begin{array}{l}\text { Menu } \\
\text { Kelola } \\
\text { Data } \\
\text { Masalah }\end{array}$ & $\begin{array}{l}\text { Menampilk- } \\
\text { an Data } \\
\text { Masalah, } \\
\text { dapat } \\
\text { melakukan } \\
\text { tambah, edit } \\
\text { dan hapus data }\end{array}$ & $\begin{array}{l}\text { Tampil Data } \\
\text { Masalah, } \\
\text { dapat } \\
\text { melakukan } \\
\text { tambah, edit } \\
\text { dan hapus } \\
\text { data }\end{array}$ & Valid \\
\hline 3. & $\begin{array}{l}\text { Menu } \\
\text { Kelola } \\
\text { Data } \\
\text { Gejala }\end{array}$ & $\begin{array}{l}\text { Menampilkan } \\
\text { Data Gejala, } \\
\text { dapat } \\
\text { melakukan } \\
\text { tambah, edit } \\
\text { dan hapus data }\end{array}$ & $\begin{array}{l}\text { Tampil Data } \\
\text { Gejala, } \\
\text { dapat } \\
\text { melakukan } \\
\text { tambah, edit } \\
\text { dan hapus } \\
\text { data }\end{array}$ & Valid \\
\hline 4. & $\begin{array}{l}\text { Menu } \\
\text { Kelola } \\
\text { Data } \\
\text { Penangan- } \\
\text { an }\end{array}$ & $\begin{array}{l}\text { Menampilkan } \\
\text { Data } \\
\text { Penanganan, } \\
\text { dapat } \\
\text { melakukan }\end{array}$ & $\begin{array}{l}\text { Tampil Data } \\
\text { Penangan- } \\
\text { an, dapat } \\
\text { melakukan } \\
\text { tambah, edit }\end{array}$ & Valid \\
\hline
\end{tabular}

\begin{tabular}{|c|c|c|c|c|}
\hline & & $\begin{array}{l}\text { tambah, edit } \\
\text { dan hapus data }\end{array}$ & $\begin{array}{ll}\text { dan hapus } \\
\text { data }\end{array}$ & \\
\hline \multirow[t]{7}{*}{5.} & Menu & Menampilkan & Tampil Data & Valid \\
\hline & Kelola & Data Basic & Basic Rule, & \\
\hline & Data Basic & Rule, dapat & dapat & \\
\hline & Rule & melakukan & melakukan & \\
\hline & & tambah, edit & tambah, edit & \\
\hline & & dan hapus data & dan hapus & \\
\hline & & & data & \\
\hline \multirow[t]{7}{*}{6.} & Menu & Menampilkan & Tampil Data & Valid \\
\hline & Kelola & Data & Pengetahua- & \\
\hline & Data & Pengetahuan, & $\mathrm{n}$, dapat & \\
\hline & Pengetahu & dapat & melakukan & \\
\hline & -an & melakukan & tambah, edit & \\
\hline & & tambah, edit & dan hapus & \\
\hline & & dan hapus data & & \\
\hline \multirow[t]{5}{*}{7.} & Menu & Menampilkan & Tampil Data & Valid \\
\hline & Kelola & Data Pasien, & Pasien, & \\
\hline & Data & dapat & dapat & \\
\hline & Pasien & melakukan & melakukan & \\
\hline & & hapus data & hapus data & \\
\hline \multirow[t]{5}{*}{8.} & Menu & Menampilkan & Tampil Data & Valid \\
\hline & Kelola & Data Admin, & Admin, & \\
\hline & Data & dapat & dapat & \\
\hline & Admin & melakukan & melakukan & \\
\hline & & $\begin{array}{l}\text { tambah, dan } \\
\text { hapus data }\end{array}$ & $\begin{array}{l}\text { tambah, dan } \\
\text { hapus data }\end{array}$ & \\
\hline \multirow[t]{7}{*}{9.} & Konsultasi & Menampilkan & Tampil & Valid \\
\hline & dari Sisi & Nama, Jenis & Nama, Jenis & \\
\hline & Pasien & Kelamin, & Kelamin, & \\
\hline & & Tanggal & Tanggal & \\
\hline & & Konsultasi & Konsultasi & \\
\hline & & Pasien dan & Pasien dan & \\
\hline & & Pertanyaan & Pertanyaan & \\
\hline \multirow[t]{8}{*}{10.} & Diagnosa & Menampilkan & Tampil & Valid \\
\hline & dari Sisi & gejala yang & gejala yang & \\
\hline & Pasien & dipilih, Hasil & dipilih, & \\
\hline & & diagnosa & Hasil & \\
\hline & & masalah kulit & diagnosa & \\
\hline & & dan & masalah & \\
\hline & & penanganan & kulit dan & \\
\hline & & & penanganan & \\
\hline \multirow[t]{4}{*}{11.} & Cetak & Menampilkan & Tampil hasil & Valid \\
\hline & Hasil dari & hasil diagnosa & diagnosa & \\
\hline & Sisi Pasien & dalam bentuk & dalam & \\
\hline & & PDF & bentuk PDF & \\
\hline \multirow[t]{2}{*}{12.} & Logout & Keluar dari & Keluar dari & Valid \\
\hline & & Aplikasi & Aplikasi & \\
\hline
\end{tabular}

\section{KESIMPULAN}

Berdasarkan Hasil implementasi dan pengujian yang telah dilakukan, terdapat beberapa kesimpulan yaitu :

1. Algoritma forward chaining dan certainty factor di dalam pembuatan sistem pakar maupun aplikasi konsultasi ini berhasil diimplementasikan dan memberikan hasil yang akurat.

2. Pada pengujian yang dilakukan, kesimpulan yang diambil oleh sistem dalam memutuskan masalah kulit 
pasien berdasarkan dari peringkat dengan nilai CFcombine tertinggi. Rata-rata yang didapat dari pengujian mencapai $94,25 \%$ sementara dalam contoh kasus yang dibahas, sistem menunjukkan hasil perhitungan sebesar 97,35\%. Hasil ini sama dengan perhitungan yang dilakukan secara manual. Kemudian sistem memberikan solusi dari masalah tersebut sesuai dengan kaidah forward chaining yaitu Regular Facial Acne Treatment.

3. Sistem yang dibangun dapat menjadi alternatif bagi masyarakat dalam mengenali kondisi kulit masingmasing.

\section{REFERENSI}

[1] H. Kusantati, P. T. Prihatin, and W. Wiana, Tata Kecantikan Kulit Untuk SMK Jilid 2, vol. 53, no. 9. Direktorat Pembinaan Sekolah Menengah Kejuruan, 2008.

[2] A. Puspita, A. F. Lestari, and H. Amalia, "Sistem Pakar Pendeteksian Dini Jenis dan Perawatan Kulit Wajah dengan Menggunakan Metode Forward Chaining," Tek. Inform. Stmik Antar Bangsa, vol. III, no. 2, pp. 121-128, 2017.

[3] I. H. Santi and B. Andari, "Sistem Pakar Untuk Mengidentifikasi Jenis Kulit Wajah dengan Metode Certainty Factor," INTENSIF J. Ilm. Penelit. dan Penerapan Teknol. Sist. Inf., vol. 3, no. 2, p. 159, 2019.

[4] N. A. Hasibuan, H. Sunandar, S. Alas, and S. Suginam, "Sistem Pakar Mendiagnosa Penyakit Kaki Gajah Menggunakan Metode Certainty Factor," Jurasik (Jurnal Ris. Sist. Inf. dan Tek. Inform., vol. 2, no. 1, p. 29, 2017.

[5] 2Rini Malfiany Ingrid Rosalia Dewi, "Perancangan Sistem Informasi Administrasi Pembayaran Pada Sdit Lampu Iman Karawang Berbasis Visual Basic 6.0,' J. Interkom, vol. 12, no. 2, pp. 4-12, 2017.

[6] H. Kusniyati and A. W. J. Putro, "Rancang Bangun Aplikasi Reminder Pengumpulan Soal Ujian Di Smk Jakarta 1 Berbasis Web," Petir, vol. 11, no. 2, pp. 191-202, 2018.

[7] M. S. Novendri, A. Saputra, and C. E. Firman, "Aplikasi Inventaris Barang Pada Mts Nurul Islam Dumai Menggunakan Php Dan Mysql," Lentera Dumai, vol. 10, no. 2, pp. 46-57, 2019.

[8] C. T. Pratala, E. M. Asyer, I. Prayudi, and A. Saifudin, "Pengujian White Box pada Aplikasi Cash Flow Berbasis Android Menggunakan Teknik Basis Path," J. Inform. Univ. Pamulang, vol. 5, no. 2, p. 111, 2020.

[9] A. A. Arwaz, T. Kusumawijaya, R. Putra, K. Putra, and A. Saifudin, "Pengujian Black Box pada Aplikasi Sistem Seleksi Pemenang Tender Menggunakan Teknik Equivalence Partitions," J. Teknol. Sist. Inf. dan Apl., vol. 2, no. 4, p. 130, 2019.

[10] S. Syamsiah, "Perancangan Flowchart dan Pseudocode Pembelajaran Mengenal Angka dengan Animasi untuk Anak PAUD Rambutan," STRING (Satuan Tulisan Ris. dan Inov. Teknol., vol. 4, no. 1, p. 86, 2019.

[11] S. Rudiarto, H. Prastiawan, A. A. Hendriawan, and M. History, "Design of Bajaj Transportation Rental Application System With First Come First Served," Int. Res. J. Comput. Sci., vol. 5, no. 06, pp. 318-330, 2018.

[12] M. Luthfi, I. H. Al Amin, and T. D. Cahyono, "Perancangan Aplikasi Berbasis Website Diagnosa Penyakit Ayam Petelur," PProceeding SINTAK 2019, no. 1, pp. 352-360,
2019.

[13] A. Nata and Hidayatullah, "Penerapan Metode Cooper Berbasis Website Dalam," J. Sci. adn Soc. Res., vol. 4307, no. February, pp. 1-6, 2020.

[14] H. K. W. A. I. K. Dede Firmansyah, "Penerapan Metode Waterfall Dalam Perancangan Sistem Informasi Penggajian Pada Smk Bina Karya Karawang,” J. Interkom, vol. 14, no. 4, pp. 13-23, 2020.

[15] H. H. Solihin, "Perancangan Sistem Informasi Penerimaan Siswa Baru Berbasis Web (Studi Kasus: Smp Plus Babussalam Bandung)," Infotronik J. Teknol. Inf. dan Elektron., vol. 1, no. 1, p. 54, 2017.

[16] R. Yusuf, H. Kusniyati, and Y. Nuramelia, "Aplikasi Diagnosis Gangguan Kecemasan Menggunakan Metode Forward Chaining Berbasis Web dengan PHP dan MYSQL," Stud. Inform. J. Sist. Inf., vol. 9, no. 1, pp. 1-13, 2016.

[17] A. Amriana, A. Y. E. Dodu, and P. R. Mas, "Pendeteksian Kerusakan Printer menggunakan Metode Forward Chaining," Ilk. J. Ilm., vol. 12, no. 1, pp. 47-57, 2020.

[18] D. M. Putra and G. W. Nurcahyo, "Sistem Pakar Menggunakan Metode Certainty Factor Dalam Akurasi Identifikasi Penyakit Panleukopenia Pada Kucing," J. Sistim Inf. dan Teknol., vol. 2, pp. 5-9, 2020.

[19] N. A. Putri, "Sistem Pakar Untuk Mengidentifikasi Kepribadian Siswa Menggunakan Metode Certainty Factor dalam Mendukung Pendekatan Guru," J. Inf. Technol. Comput. Sci., vol. 1 Nomor 1, no. Juni 2018, pp. 78-90, 2018.

[20] A. H. Kridalaksana, A. Hidayat, U. Mulawarman, and D. Cahyadi, "Sistem Pakar Diagnosa Kerusakan Kamera DSLR Menggunakan Metode Certainty Factor Sequential," Pros. Semin. Nas. Ilmu Kridalaksana, A. H., Hidayat, A., Mulawarman, U., Cahyadi, D. (2019). Sist. Pakar Diagnosa Kerusakan Kamera DSLR Menggunakan Metod. Certain. Factor Seq. Pros. Semin. Nas. Ilmu Komput. Dan Teknol. Info, vol. 4, no. 1, pp. 1-5, 2019. 